\title{
The Effect of Climate Change on Abundance and Diversity of Ant in Tuhaha Forest at Mollucas Province on Indonesia
}

\author{
Fransina Latumahina* and Gun Mardiatmoko \\ Forestry Department, Faculty of Agriculture, Pattimura University \\ Ambon-97237, Indonesia \\ *Corresponding author
}

\section{A B S T R A C T}

\section{Keywords \\ Protection Forest, Species abundance, Climate change, Ants \\ Article Info \\ Accepted: \\ 18 April 2019 \\ Available Online: \\ 10 May 2019}

\begin{abstract}
The study was conducted in the Protected Forest area of Tuhaha Village, Saparua SubDistrict, Mollucas Province, in May - July 2018 to determine the presence, abundance, diversity and evenness of ant species in relation to climate change in Mollucas. Ants were collected by three methods, namely Hand Collecting, Pitfall trap with soapy water bait using a detergent brand Rinso, bait trap with sugar water bait and tuna fish. The results of the study found 35 species of ants as many as 1866 tails, the diversity of species 1.47 were classified as moderate, species richness 4.51 and evenness of type 0.41 with a distribution pattern of 0.19 , which was classified as grouped type. Correlation analysis on factors of air temperature climate and air humidity found that the results of $\mathrm{R}$ square of air temperature were $0.003 \%$, air humidity was $0.63 \%$, and rainfall was $3.25 \%$ for the number of ants.
\end{abstract}

\section{Introduction}

Ecosystem changes due to climate warming have become a serious problem because climate change occurs in almost all types of ecosystems gradually. The increase in the surface temperature of the earth, the melting of snow at the North Pole and rising sea levels and disturbances of biodiversity are a picture of the impact of climate change. When climate change occurs, ants will respond to changes that occur in ecosystems, ants can become indicator species to monitor environmental changes due to active colony habits, long activity seasons, high diversity and density, and high relationships with environmental factors. A total of 31 researchers from six countries proposed standard monitoring methods to activate ant monitoring (Agosti et al., 2000). Distribution of Argentine ants, Linepithema humile Mayr has changed due to warming of air temperatures in a period of 1 year (Roura-Pascual et al., 2004), consequently moving from Southwest Asia, and if climate change continues, the distribution of Argentine ants will decline in the tropics and extends to high latitudes area. Even in Korea, it is no longer found because it has moved to Manchuria. Fire ants (Solenopsis invicta Baren) from South America, invaded the southern United States and weregrowing rapidly due to changes in temperature and 
rainfall over the past 10 years (Sutherst and Maywald, 2005). Ant communities in Australia responded actively to disruption of human presence and change climate. The diversity and composition of ants found for more than 20 years in Australia has undergone changes due to human disturbances and climate change. (Majer 1983; Andersen 1990, 1997a, b; Bestelmeyer and Wiens 1996; Majer and Nichols 1998; Peck et al., 1998; Bisevac and Majer 1999; Agosti et al., 2000; Mitchell et al., 2002). Majer and Nichols (1998) found that ant communities in damaged ecosystems and increased air temperatures had a lower diversity of species and a greater number of Dolichoderines (subfamily of highly active ants). Distribution of ants in Jeju Island in 2006 decreased vertically every $0.5^{\circ} \mathrm{C}$ temperature increase and every $100 \mathrm{~m}$ height increase in the mountain region, Kwon et al., (2014). The Latumahina study, 2014, found changes in microclimate and the presence of humans reduced ant populations in the Sirimau Protection Forest area in Mollucas by $40 \%$. From the above phenomena, this study helped to predict the relationship of climate change with the abundance and diversity of ant species in the protected forest of Tuhaha Village, Saparua District, Central Mollucas Regency.

\section{Materials and Methods}

\section{Time and location of research}

The study was conducted in the Protected Forest of Tuhaha Village, Central Mollucas Regency, Mollucas Province, which is astronomically located at $3^{\circ} 32$ '00 "to 3o 34' 00" South Latitude and $128^{\circ} 40$ '30 "East Longitude, at an altitude of $68 \mathrm{~m}$ asl.

\section{Tools and materials}

The equipment used was plastic cups, plastic plates, cameras, raffia, machetes, $\mathrm{pH}$ meters, electron microscopes, lux meters, roll meters, phi bands, meter meters, Garmin GPS, hygrometers, earth drills, soil and air thermometers. Materials included ants, canned fish, vegetation, soil, water, sugar, and detergent.

\section{Research procedure}

Taking ants used the method (1) Hand Collecting (2) Pitfall trap and (3) Bait trap. The Pitfall trap method used a mixture of water and detergent, the bait trap method used Tuna bait and sugar solution. Samples were grouped based on sampling methods and preserved with $70 \%$ alcohol, then identified up to species level using the book of Identification Guides to the Ant Genera of The World (Bolton, 1997). Vegetation inventory used Continuous strip sampling methods on plots measuring $20 \mathrm{~m}$ x $20 \mathrm{~m}$ for tree level , 10 $\mathrm{mx} 10 \mathrm{~m}$ for pole level, $5 \mathrm{mx} 5 \mathrm{~m}$ for sapling and $2 \mathrm{mx} 2 \mathrm{~m}$ for seedlings. Micro climate data in the form of air temperature and humidity, and soil data such as temperature and soil moisture.

\section{Data analysis}

Ant potential was known from species richness, diversity using diversity index, similarity types using similarity index, evenness using Jaccarrd index and similarity using index evenness similarity. Distribution patterns and to compare the presence of ants used Multi-dimensional scaling MDS) as well as to determine the relationship between the characteristics of protected forests and the diversity of ants depicted in two-dimensional graphs. Vegetation closure was analized by using NDVI, microclimate that included air temperature, air humidity and rainfall. The relationship of climate factors to the diversity of species and the abundance of ant species was known by correlation and regression analysis. 


\section{Results and Discussion}

\section{Species wealth, type abundance, diversity and evenness of ant types}

The spread of ants in the Tuhaha Village Protection Forest can be seen in Table 1 and Figure 1.

The results of the ants collection with 3 methods found 35 types with species richness of 4.51 classified as moderate, type evenness index of 0.41 where the spread of ants in the Tuhaha Village Protected Forest was uneven $(<1)$. The distribution pattern was 0.19 where ants in the protected forest live spreadly. The type diversity $\left(\mathrm{H}^{\prime}\right)$ value is 1.47 as medium. The values of the three parameters above were influenced by a) Composition of species and structure of vegetation. Changes in vegetation cover are related to food availability and nesting for activities. The results of the NDVI analysis showed that vegetation density in Tuhaha Village Protected Forestwas classified as medium with an area of 441.132 ha. Changes in plant structure on a land always correlate with the diversity and abundance of ants (Agosti et al., 2000) so that the presence of certain ants is assumed to be determined by the constituent vegetation of the region. The composition of ant types will be different based on the type of vegetation (Herwina AND Yaherwandi, 2012) b) Availability of nests. The availability of nests affects the abundance, productivity and structure of ant colonies. The nest is used as a place to store food, food cultivation, and a sanctuary for queens and colonies. At the time of the study, it was found the nest of Dolichoderus thoracicus on the mound around Acasia (Acacia mangium), so that it was suspected that this species like the Acacia Tree as a shelter. c) Availability of food, Foods containing glucose and protein will affect the development and reproduction of ants (Latumahina, 2015). At the time of the study, it was found ants that like the solution of sugar and fish together, only sugar or fish solutions and vice versa or not even found in both types of food. The types of food and foraging activities greatly influence the composition of ants in protected forests. Foraging activities are influenced by three factors, namely internal needs (hunger and production), food sources and microclimates. The composition of ants in forested areas is higher and varied compared to non-forest areas because of physical differences in ecosystems, food availability, nest availability, predation and competition among ants. The distribution of ants in each lane varied, where Anochetus Graeffa predominating in lanes I and IV with a total of 82 individuals. Echinoplalineata dominated lane II, V and IX with 108 individuals. Polirachys dives dominated lane III and VII with 131 tails. Leptogenys diminuta dominated lane VI with 94 individuals. Dolichoderus thoracicus dominated lane VIII with 86 individuals, and Meranoplus bicolor dominated lane $\mathrm{X}$ with a total of 32 individuals.

Anochetus graeffeid was found by using the hand collecting method around the roots of Acacia (Acacia mangium) and Siripopar (Piper miricatum). This type was also found with sugar solution bait because it was found as many as 20 tails more than the tuna fish feed (5 tails). Many of Echinoplalineata, Polirachys dives and Leptogenysdiminutawere found with a tuna fish bait. It was assumed that Tuna is a source of protein for 3 types of ants because tuna can form hormones, enzymes, and maintain the muscle tissue of ants. Tuna is a source of mineral-rich protein, especially magnesium, selenium, phosphorus and is thought to be highly preferred by all three types. Tuna with high protein content was thought to help the ants produce eggs and larvae to grow into adult ants.

The black ant Dolichoderus thoracicus dominated lane VIII found at an altitude of 65 $\mathrm{m}$ above sea level around the roots of Oranges 
(Citrus sinensis), Srikaya (Annona squamosal), Guava (Syzigium cumini L) and Mango (Mangifera indica). Ants clustered on plant stems and leaves, dried leaf foliage and plant litter of forest nutmeg (Myristica fragrans). At the time of the study, the rainfall was very high, with air humidity $83.2 \%$, air temperature $28^{\circ} \mathrm{C}$. Dolichoderus thoracicus were active on the top of plants to get sunlight, but during the day when the temperature of air was hot, they hide between the leaves and bottom of the rock which was protected from the sun's rays. Dolichoderus thoracicus was found more because the research was carried out during the rainy season in Mollucas. Presumably, food sources and vegetation were available to make nests in supporting the growth of coloniesduring the rainy season. Multi Dimensional Scaling (MDS) analysis was carried out to find out the relationship between habitat characteristics with soilpH variable, organic matter, soil temperature $\left({ }^{\circ} \mathrm{C}\right)$, air temperature $\left({ }^{0} \mathrm{C}\right)$, air humidity $(\%)$, soil moisture (\%), rainfall (mm / day), and Noise (db) with ant diversity can be seen in the twodimensional graph below.

Based on Figure 2, the diversity of ant species on Lanes $6,7,8$, and 9 was closely related to soil $\mathrm{pH}$, soil temperature, and air noise. On lane 10 , it tended to be related to the humidity of air and organic matter. Soil moisture was closely related to the diversity of ant species on lanes 1,2,3, and 4, while the diversity of ant types in lane 5 was closely related to rainfall and air temperature.

\section{Vegetation closure}

The results of the NDVI analysis can be seen in Figure 3 below.

This study used NDVI values, which were reclassified into three categories as in Table 2. Table 2 shows the vegetation density in Tuhaha Village Protected Forest classified in the medium category. This was caused by anthropogenic damage due to illegal hunting of wild boar (Susscrofa) and wild dogs (Cuonalpinus) by residents, clearing of forests for cassava gardens, taking Aren (Arengapinnata) on a regular basis for making "Saparua" brown sugar and home-made materials. This condition has shown symptoms of deforestation in protected forests. Panta et al., (2008) stated that deforestation, which is the change in forest cover to non-forest due to forest degradation, can reduce the quality of forest canopies and the vertical structure of forest canopies in the long term. The reason for the decision of the Tuhaha Village community was to convert the forest due to clearing of forests with reduced costs, weak village supervision, and economic factors of the people. Suhendang (2002) states that the area of permanent forestlandand forest carrying capacity is limited, while human needs continue to increase due to a decrease in the area and quality of the forest.

\section{Relationship between climate change and the abundance and diversity of ants}

The results of $\mathrm{R}$ square value of soil temperature is $0.21 \%$, air temperature $0.05 \%$, air humidity, $2.02 \%$ and soil moisture $1.47 \%$ against the abundance of ants. In Tuhaha Village Protected Forest, It was known that air humidity variable has the highest correlation with the abundance of ants of $2.02 \%$ and the lowest correlation of air temperature with a correlation value of $0.05 \%$. This showed that the four variables above have a relationship with the abundance of ants but there were other variables that were more influential than this correlation.

The results of the correlation analysis with soil temperature, air temperature, soil moisture and air humidity there are variations in the response of each type to the four parameters (Fig. 4 and 5). 
Table.1 Species Wealth, Species Abundance, and Diversity of Ant Types

\begin{tabular}{|c|c|c|c|c|}
\hline Lane & Species name & $\begin{array}{l}\text { Number of } \\
\text { individuals }\end{array}$ & $\begin{array}{l}\text { Type } \\
\text { abundance }\end{array}$ & $\begin{array}{l}\text { Species } \\
\text { diversity }\end{array}$ \\
\hline \multirow[t]{9}{*}{ I } & Acropygamoluccana roger & 26 & 13,13 & 0,111 \\
\hline & Aenictusceylonicus & 30 & 15,15 & 0,116 \\
\hline & Anochetusgraeffei & 39 & 19,70 & 0,125 \\
\hline & Cardiocondylanuda & 16 & 8,08 & 0,098 \\
\hline & Cerapachysjacobsoni & 7 & 3,54 & 0,083 \\
\hline & Cerapachyssuscitatus & 19 & 9,60 & 0,102 \\
\hline & Crematogasterampullaris & 20 & 10,10 & 0,103 \\
\hline & Crematogasterdifformis & 20 & 10,10 & 0,103 \\
\hline & Crematogasterelegans & 21 & 10,61 & 0,105 \\
\hline \multirow[t]{8}{*}{ II } & Dolichoderusthoracicus & 20 & 15,87 & 0,120 \\
\hline & Echinoplalineata_lineata & 26 & 20,63 & 0,129 \\
\hline & Hypoponerabugnioni & 19 & 15,08 & 0,119 \\
\hline & Aenictusceylonicus & 12 & 9,52 & 0,106 \\
\hline & Pachycondylaluteipes & 15 & 11,90 & 0,111 \\
\hline & Cardiocondylanuda & 7 & 5,56 & 0,094 \\
\hline & Diacammarugosum & 12 & 9,52 & 0,106 \\
\hline & Leptogenysdiminuta & 15 & 11,90 & 0,111 \\
\hline \multirow[t]{9}{*}{ III } & Pheidologetonmelanocephalus & 26 & 8,90 & 0,100 \\
\hline & Polyrhachis dives & 77 & 26,37 & 0,136 \\
\hline & Anochetusgraeffei & 29 & 9,93 & 0,103 \\
\hline & Cryptoponetestaceae & 45 & 15,41 & 0,116 \\
\hline & Diacammarugosum & 10 & 3,42 & 0,083 \\
\hline & Dolichoderusbeccarii & 45 & 15,41 & 0,116 \\
\hline & Dolichoderusthoracicus & 13 & 4,45 & 0,086 \\
\hline & Odonthoponeratranversainfuscata & 29 & 9,93 & 0,103 \\
\hline & Odontomachustyrannicus & 18 & 6,16 & 0,092 \\
\hline \multirow[t]{6}{*}{ IV } & Acropygamoluccana & 24 & 13,26 & 0,123 \\
\hline & Aenictusceylonicus & 42 & 23,20 & 0,140 \\
\hline & Anochetusgraeffei & 43 & 23,76 & 0,140 \\
\hline & Camponotusreticulatus roger & 16 & 8,84 & 0,114 \\
\hline & Cerapachysjacobsoni & 27 & 14,92 & 0,127 \\
\hline & Cerapachyssuscitatus & 29 & 16,02 & 0,129 \\
\hline \multirow[t]{4}{*}{ V } & Cryptoponetestaceae & 16 & 16,00 & 0,141 \\
\hline & Echinoplalineata_lineata & 29 & 29,00 & 0,154 \\
\hline & Leptogenysdiminuta & 24 & 24,00 & 0,150 \\
\hline & Odonthoponeratranversainfuscata & 31 & 31,00 & 0,155 \\
\hline \multirow[t]{7}{*}{ VI } & Pachycondylajavana & 26 & 15,29 & 0,123 \\
\hline & Pachycondylaluteipes & 25 & 14,71 & 0,122 \\
\hline & Polyrachisbellicosa & 25 & 14,71 & 0,122 \\
\hline & Technomyrmexkraepelin & 20 & 11,76 & 0,115 \\
\hline & Hypoponerabugnioni & 26 & 15,29 & 0,123 \\
\hline & Leptogenysdiminuta & 36 & 21,18 & 0,133 \\
\hline & Myrmicariabrunneasubcarinata & 12 & 7,06 & 0,104 \\
\hline VII & Oecophyllasmaragdina & 15 & 4,32 & 0,079 \\
\hline
\end{tabular}


Int.J.Curr.Microbiol.App.Sci (2019) 8(5): 2391-2396

\begin{tabular}{|c|c|c|c|c|}
\hline & SUBNITIDA & & & \\
\hline & Platythyreaparallela & 35 & 10,09 & 0,098 \\
\hline & Polyrhachisabdominalis & 17 & 4,90 & 0,081 \\
\hline & Polyrhachisbellicosa & 26 & 7,49 & 0,090 \\
\hline & Polyrhachis dives & 54 & 15,56 & 0,112 \\
\hline & Tetramoriumsmithi & 35 & 10,09 & 0,098 \\
\hline & Tetraponera attenuate & 30 & 8,65 & 0,093 \\
\hline & Odonthoponeratranversainfuscata & 34 & 9,80 & 0,097 \\
\hline & Pachycondylaluteipes & 30 & 8,65 & 0,093 \\
\hline & Polyrhachisabdominalis & 35 & 10,09 & 0,098 \\
\hline & Odontomachustyrannicus & 36 & 10,37 & 0,098 \\
\hline \multicolumn{5}{|c|}{ VIII } \\
\hline & Aenictusceylonicus & 15 & 12,71 & 0,129 \\
\hline & Tetramoriumpacificum Mayr & 26 & 22,03 & 0,142 \\
\hline & Dolichoderusthoracicus & 28 & 23,73 & 0,144 \\
\hline & Hypoponerabugnioni & 26 & 22,03 & 0,142 \\
\hline & Tetraponera attenuate & 23 & 19,49 & 0,139 \\
\hline \multirow[t]{5}{*}{ IX } & Echinoplalineata_lineata & 35 & 35,00 & 0,154 \\
\hline & Pheidologetonmelanocephalus & 13 & 13,00 & 0,129 \\
\hline & Aenictusceylonicus & 14 & 14,00 & 0,131 \\
\hline & Odontomachustyrannicus & 13 & 13,00 & 0,129 \\
\hline & Crematogasterelegans & 25 & 25,00 & 0,146 \\
\hline \multirow[t]{10}{*}{$\mathrm{X}$} & Dolichoderusbeccarii & 23 & 9,83 & 0,100 \\
\hline & Dolichoderusthoracicus & 25 & 10,68 & 0,102 \\
\hline & Echinoplalineata_lineata & 18 & 7,69 & 0,093 \\
\hline & Hypoponerabugnioni & 14 & 5,98 & 0,088 \\
\hline & Leptogenysdiminuta & 19 & 8,12 & 0,094 \\
\hline & Meranoplus bicolor & 32 & 13,68 & 0,110 \\
\hline & Myrmoterasbinghami & 27 & 11,54 & 0,104 \\
\hline & Myrmoterasjacquelinea & 24 & 10,26 & 0,101 \\
\hline & Odonthoponeratranversainfuscata & 25 & 10,68 & 0,102 \\
\hline & Odontomachustyrannicus & 27 & 11,54 & 0,104 \\
\hline
\end{tabular}

Table.2 Area of vegetation cover based on NDVI analysis

\begin{tabular}{|c|c|c|}
\hline Vegetation density & Forest Area & Location \\
\hline Rarely Density & $175.008 \mathrm{Ha}$ & Protected forest area \\
\hline Medium density & $441.132 \mathrm{Ha}$ & Protected forest area \\
\hline High density & $100.465 \mathrm{Ha}$ & Protected forest area \\
\hline
\end{tabular}


Table.3 Types of ants with a low response to air temperature, air humidity, soil temperature and soil moisture

\begin{tabular}{|r|l|c|c|c|c|c|}
\hline No. & \multicolumn{1}{|c|}{ Ant type } & $\begin{array}{c}\text { Number of } \\
\text { individuals }\end{array}$ & $\begin{array}{c}\text { Relative } \\
\text { Abundance }\end{array}$ & Frequency & $\begin{array}{c}\text { Relative } \\
\text { Frequency }\end{array}$ & $\begin{array}{c}\text { Important } \\
\text { Index } \\
\text { Value }\end{array}$ \\
\hline 1 & Anochetus graeffei & 56 & 5,95 & 0,06 & 4,05 & 10,003 \\
\hline 2 & Camponotusreticulatus roger & 8 & 0,86 & 0,02 & 1,35 & 2,209 \\
\hline 3 & Cerapachysja cobsoni & 17 & 1,82 & 0,04 & 2,70 & 4,525 \\
\hline 4 & Cryptoponetestaceae & 31 & 3,27 & 0,04 & 2,70 & 5,972 \\
\hline 5 & Dolichoderus beccarii & 34 & 3,64 & 0,04 & 2,70 & 6,347 \\
\hline 6 & Leptogenys diminuta & 47 & 5,04 & 0,08 & 5,41 & 10,443 \\
\hline 7 & Myrmicariabrunnea subcarinata & 6 & 0,64 & 0,02 & 1,35 & 1,994 \\
\hline 8 & Oecophyllasmaragdina Subnitida & 8 & 0,80 & 0,02 & 1,35 & 2,155 \\
\hline 9 & Pachycondylajavana & 13 & 1,39 & 0,02 & 1,35 & 2,745 \\
\hline 10 & Technomyrmex Kraepelin & 10 & 1,07 & 0,02 & 1,35 & 2,423 \\
\hline & Total & 933 & 100 & 1,48 & 100 & 200 \\
\hline
\end{tabular}

Figure.1 Tuhaha protected forest

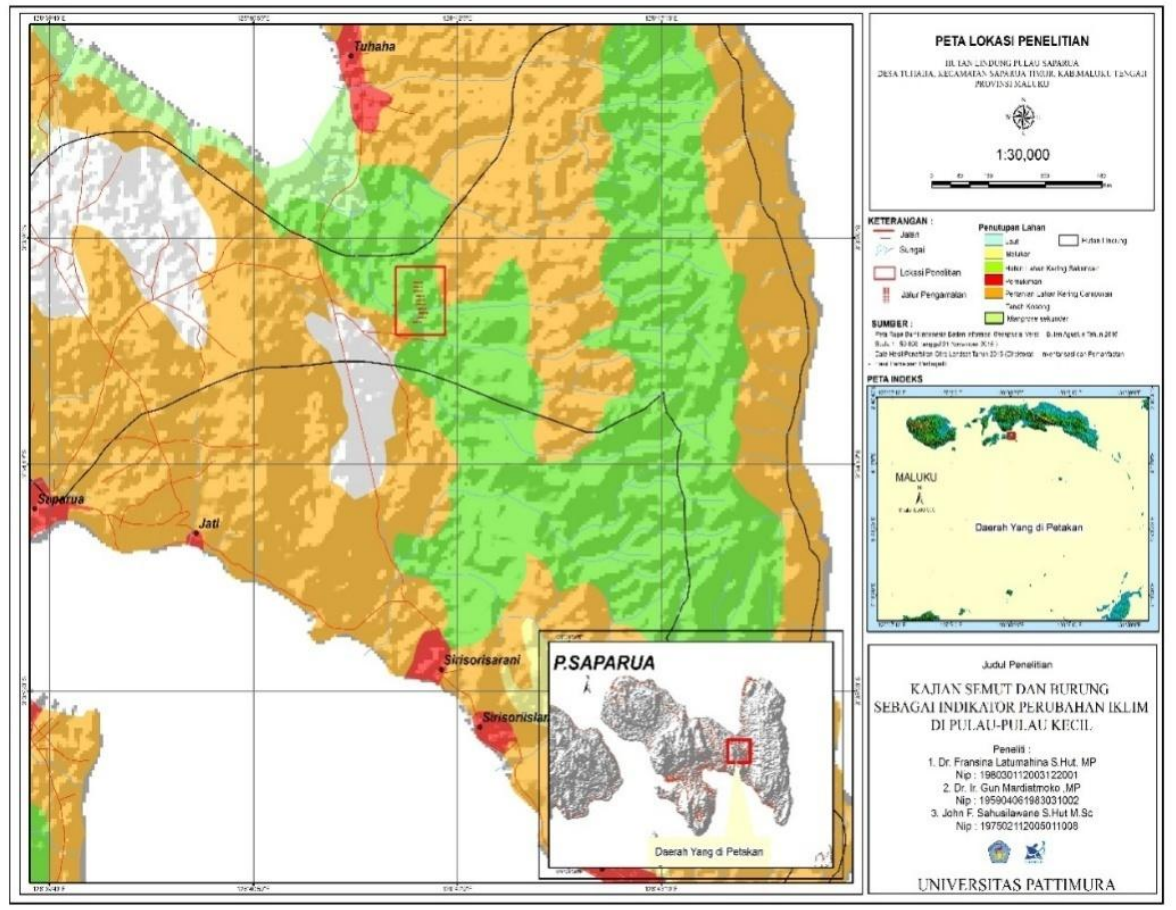


Figure.2 The two-dimensional positioning map of relationship between island characteristics (Environment) and ants diversity in Tuhaha village protected forest

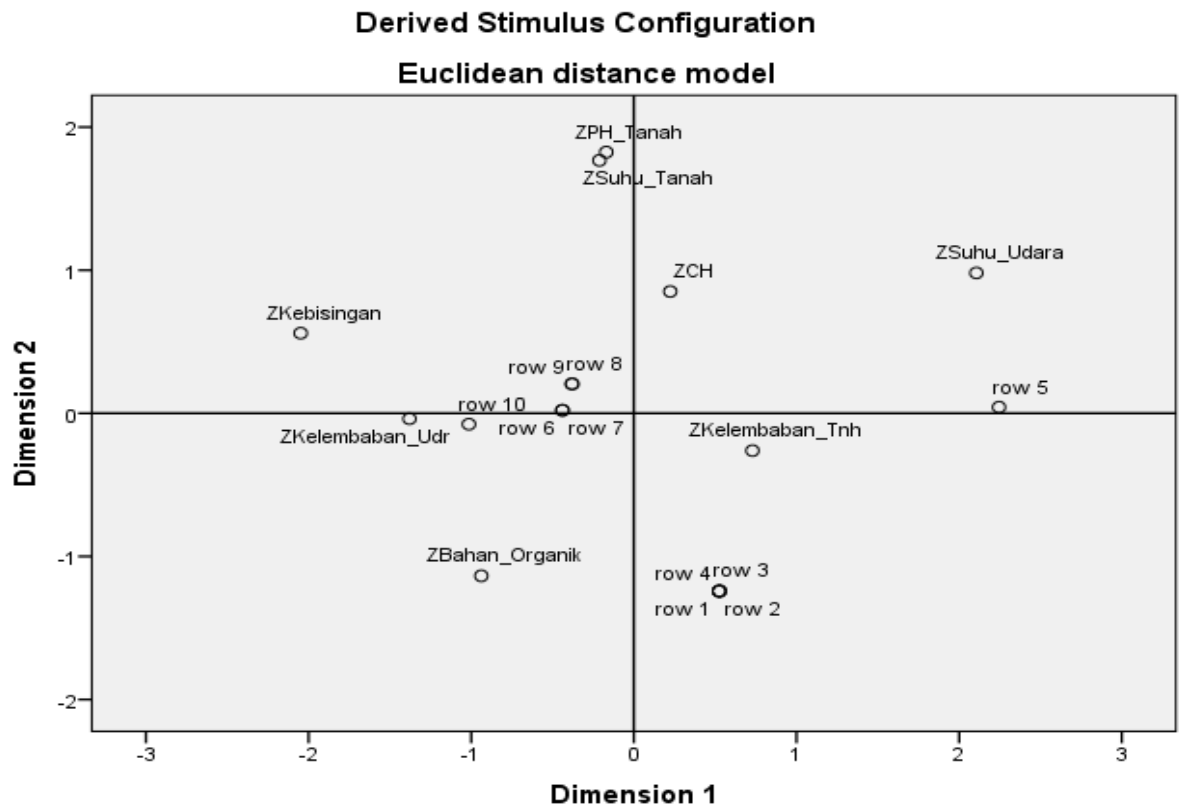

Figure.3 Results of NDVI analysis of vegetation density of Tuhaha village protected forest

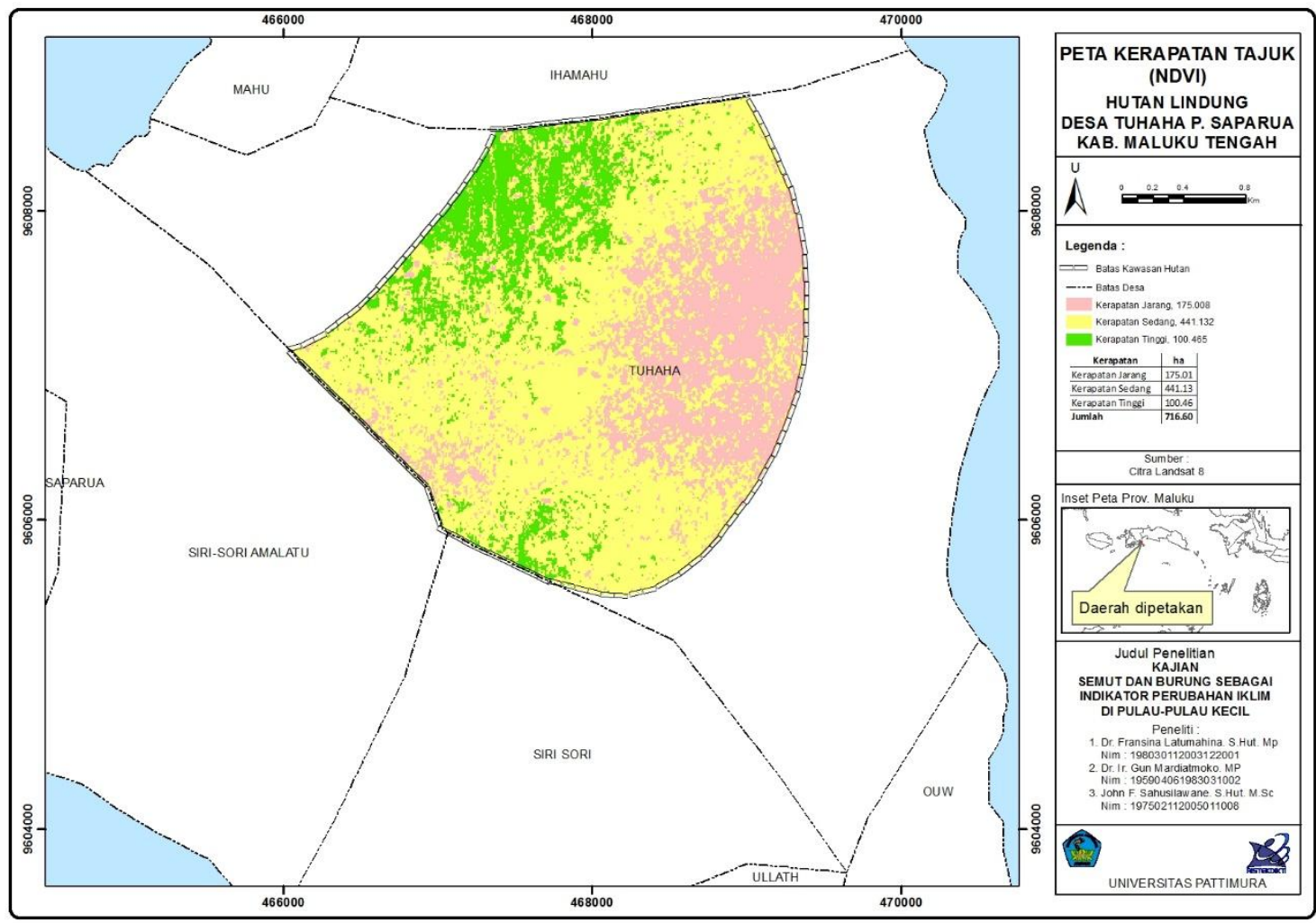


Figure.4 Relationship of soil temperature, air temperature, soil moisture, air humidity to types diversity and ant types abundance
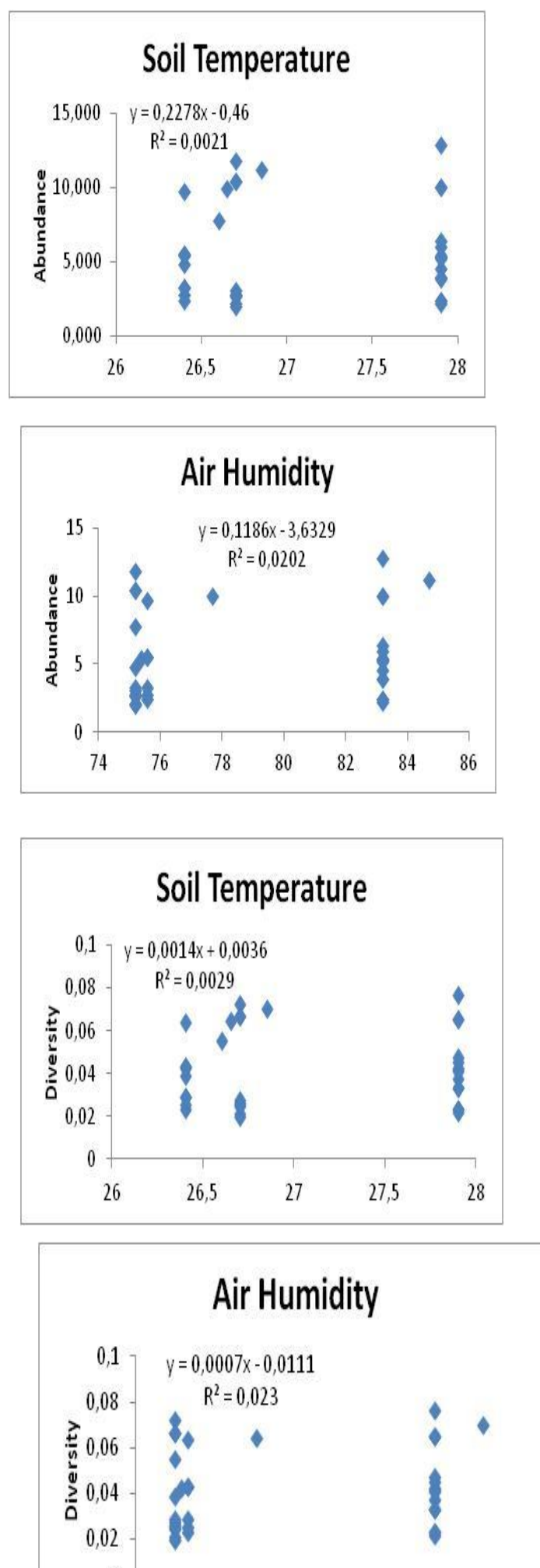
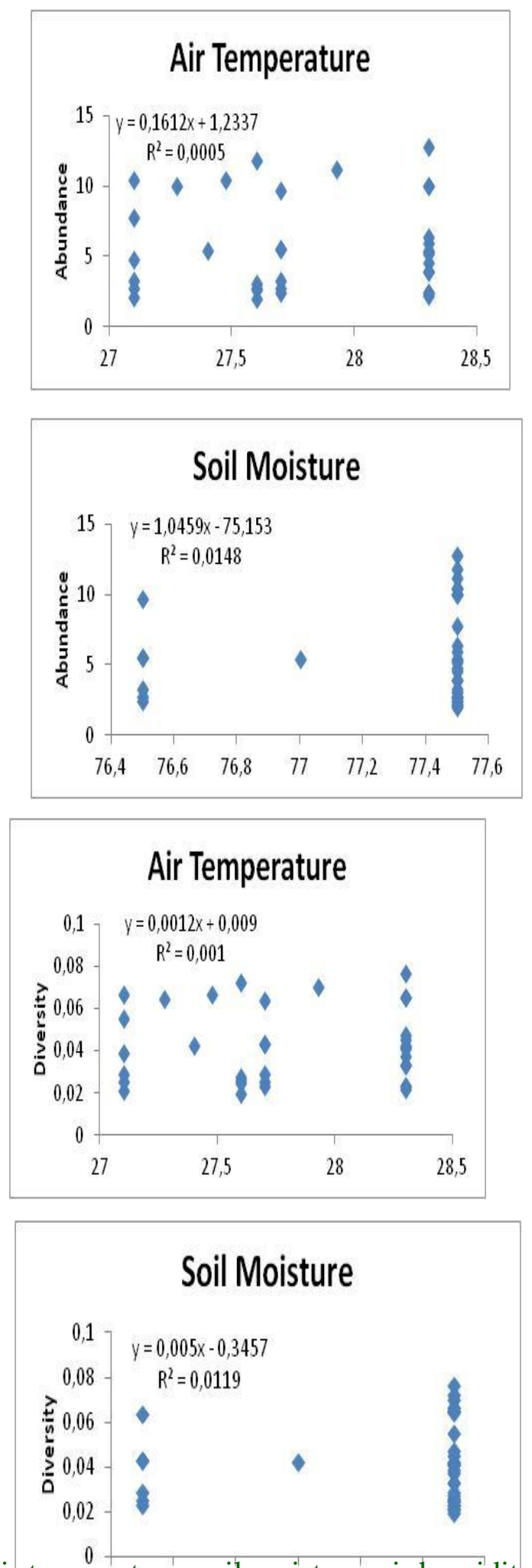

Figure.5 Re elationship of soil tęmperature 
rainfall to abundance and number of ant individuals
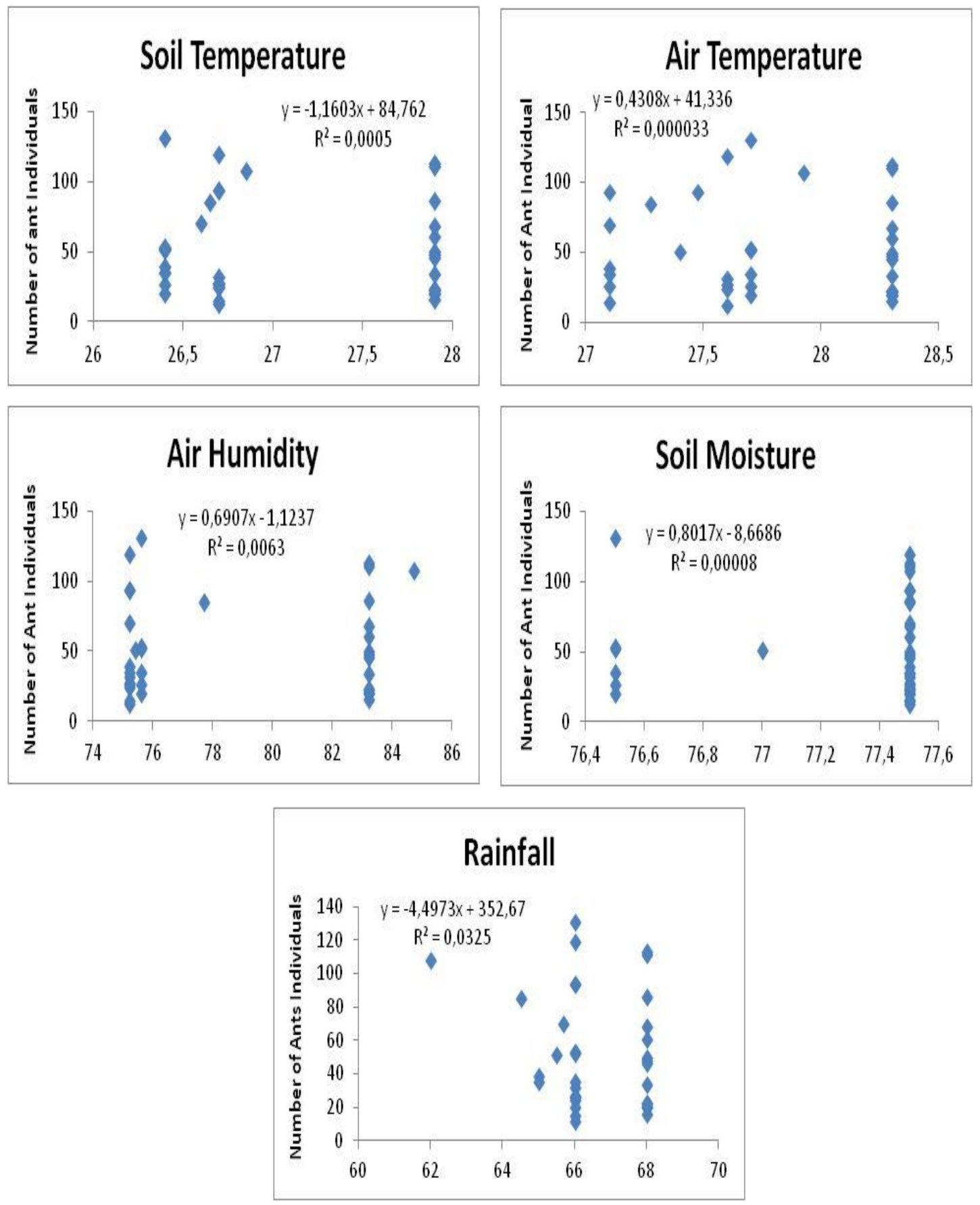

Of the 35 types of ants found, only 14 types correlated with soil temperature, 14 types of air temperature, 1 type of air humidity and 1 type soil moisture. This is due to changes in habitat conditions, food availability, microclimate, habitat disturbance due to natural and anthropogenic factors and climate change. The
ANOVA test results showed that the presence of ants in the Tuhaha Village Protected Forest had a significant influence but it was not tangible on the abundance and ant species diversity. Correlation analysis of the presence of ant was significantly not influenced by air temperature and air humidity. It was suspected 
that the type of ants found have a range of life and are active at temperatures and humidity of air and wide land so that at micro temperatures between $27^{\circ} \mathrm{C}-28.5^{\circ} \mathrm{C}$ and micro air humidity $75 \%-85 \%$ did not affect the life of ants found. Lubertazzi and Tschinkel (2003) pointed out that the temperature and air humidity that are too low or high will put pressure on the forms of nests, productivity and structural communities. Soil temperature and soil moisture of $26^{\circ} \mathrm{C}-28^{\circ} \mathrm{C}$ and $76.5 \%-77.5 \%$ were assumed to be suitable for ant life in the Tuhaha village protected forest area.

The table 3 shows 10 types of ants that are not able to adapt to air temperature changes, air humidity and rainfall that impact soil temperature and soil moisture in protected forests. As a result, daily activities, reproductive patterns, dietary patterns and the role of ants in the food chain were disrupted. Extreme microclimate disrupted the spread of seeds by ants, which could affect biodiversity in the Tuhaha Village Protected Forest. The temperature dropped and air humidity increased due to increased rainfall, Myrmicaria brunneasubca hiding between the litter of Acacia and Mahogany leaves, and did not come out looking for food so that it was only found as many as 8 tails.

Alofs, K.M. \& Fowler, NL, 2010 says the average ant takes about ten hours a day at normal temperatures, when the air temperature rises by half a degree, the ants will remain in the nest under the ground and feed for only one hour. Oecophyllas maragdina Subnitida were found among Pala and Macila Tree leaves at $09.00-10.00$ and $15.00-16.00$ of eastern Indonesian time. They could not be found outside these hours period. It was assumed that the average air temperature was $28.3^{\circ} \mathrm{C}$, air humidity is $83.2 \%, 68 \mathrm{~mm} /$ day, suitable for this type of activity, foraging, nesting and reproductive activities. Myrmicaria brunnea subcarinatam had a low ability to adapt to the microclimate in protected forest areas, so that only 8 birds were found. At the time of the study, it was found that Rangrang nests on the
Chocolate plant (Theobroma cacao L) were assumed to protect chocolate from ladybug attack, thus increasing the quality and amount of harvest. When there is a change in the microclimate in a habitat, the ants will respond by adapting, moving, or extinct. It is caused ants will die and will be followed by the extinction of the colony if they do not follow climate change.

In conclusion, of the 35 types of ants found, there were only 14 types correlated with soil temperature, 14 types of air temperature, 1 type of air humidity and 1 type of soil moisture. This was due to changes in habitat conditions, food availability, microclimate, habitat disturbance due to both natural and anthropogenic factors and climate change. The main factors that interact with the population, abundance and diversity of ant species in the Tuhaha village protected forest were air temperature and air humidity.

\section{Acknowledgement}

The author would like to thank the Government of the Republic of Indonesia through the Ministry of Research and Technology for providing research grants through the 2018 Basic Competency Grant Scheme.

\section{References}

Agosti D, Majer JD, Alonso LE, and Schultz TR. editors. 2000 Ants: Standard Methods for Measuring and Monitoring Biodiversity. Washington: Smithsonian Institution Press.

Agosti D, Majer JD, Alonso LE, and Schultz TR. editors. 2000 Ants: Standard Methods for Measuring and Monitoring Biodiversity. Washington: Smithsonian Institution Press.

Alofs, K.M. and Fowler, N.L, 2010. Habitat fragmentation caused by woody plant encroachment inhibits the spread of an invasive grass. Journal of Applied Ecology, 47. 338-347.

Bolton B. 1997 Identification Guide to the Ant 
Genera of the World. Cambridge: Harvard University Press.

Herwinadan Yaherwandi. 2012. Study of Ants (Hymenoptera: Formicidae) in Solok District Cacao Plantation, West Sumatera. Proceeding Semirata BKS-PTN B. Medan. ISBN 978-602-9155-20-8

Roura-Pascual, N., Suarez, A.V., Gómez, C., Pons, P., Touyama, Y., Wild, A.L. \& Peterson, A.T. 2004. Geographical potential of Argentine ants (Linepithema humile Mayr) in the face of global climate change. Proceedings of the Royal Society B: Bio-logical Sciences, 271: 2527-2534.

Sutherst dan Maywald, 2005. A Climate Model of the Red Imported Fire Ant, Solenopsis invicta Buren (Hymenoptera: Formicidae): Implications for Invasion of New Regions, Particularly Oceania Environmental Entomology, Volume 34, Issue 2, 1 April 2005, Pages 317-335, https://doi.org/10.1603/0046-225X34.2.317.

Majer, J.D. 1983; Andersen 1990, 1997a, b; Bestelmeyer dan Wiens 1996; Majer dan Nichols 1998; Peck dkk. 1998; Bisevac dan Majer 1999; Agosti dkk. 2000 ; Mitchell et al., 2002.Ants: Bio-indicators of minesite rehabilitation, land-use, and land conservation. Environmental Management. Volume 7, Issue 4, pp 375383.

Majerdan, J.D. and O.G. Nichols. 1998. Longterm recolonization patterns of ants in Western Australian rehabilitated bauxite mines, with reference to use as indicators of restoration success. Journal of Applied Ecology 35: 161-181.

Kwon MJ, et al., 2014. Molecular genetic analysis of vesicular transport in
Aspergillus niger reveals partial conservation of the molecular mechanism of exocytosis in fungi. Microbiology 160 (Pt 2):316-29.

Latumahina, Musyafa, Sumardi, Nugroho Susetya Putra. 2014. Penyebaran Semutpada Hutan Lindung Sirimau Kota Ambon. Bumi Lestari Journal of Environment [Spread of Ants in the Sirimau Protection Forest of Ambon City. Sustainable Earth Journal]. Vol. 14, No. 2, Jan. 2016.

Latumahina, 2015. Respon Semut Terhadap Kerusakan Antropogenikdalam Hutan Lindung Sirimau Ambon. Jurnal Manusiadan Lingkungan Pusat Studi Lingkungan [Ant Response to Anthropogenic Damage in the Sirimau Protection Forest of Ambon. Human Journal and Environment Center for Environmental Studies]. Vol 22, No 2.

Lubertazzi D, Tschinkel WR. 2003 Ant community change across a ground vegetation gradient in north Florida's longleaf pine flat woods. Journal of Insect Science. 3:21. Available online at: insectscience.org/3.21. [PMC free article][PubMed]

Panta et al, 2008. Temporal mapping of deforestation and forest degradation in Nepal: Applications to forest conservation. Forest Ecology and Management 256(9):1587-1595. DOI 10.1016/j.foreco.2008.07.023

Suhendang. 2002. Pengantar Ilmu Kehutanan Bogor [Introduction to Bogor Forestry Sciences]: Yayasan Penerbit Fakultas Kehutanan, Institut Pertanian Bogor.

\section{How to cite this article:}

Fransina Latumahina and Gun Mardiatmoko. 2019. The Effect of Climate Change on Abundance and Diversity of Ant in Tuhaha Forest at Mollucas Province on Indonesia. \& Coss.). Int.J.Curr.Microbiol.App.Sci. 8(05): 2397-2408. doi: https://doi.org/10.20546/ijcmas.2019.805.284 